\title{
PERMISIVISME MASYARAKAT TERHADAP PRAKTIK PROSTITUSI DI KOTA BANDUNG
}

\author{
${ }^{1}$ Dasim Budimansyah, ${ }^{2}$ Syaifullah, ${ }^{3}$ Delilah Nurzaidah \\ 'Dosen MKDU/ Prodi Pendidikan Sosiologi/ Pascasarjana \\ ${ }^{2}$ Dosen MKDU/ Prodi Pendidikan Sosiologi/ Pascasarjana \\ 3Universitas Pendidikan Indonesia \\ E-mail: budimansyah@upi.edu
}

\begin{abstract}
ABSTRAK
Realitas sikap masyarakat yang permisif (serba membolehkan/acuh) terhadap praktik prostitusi yang hingga kini terus berkembang di tengah masyarakat kota Bandung. Masalah tersebut merupakan tantangan bagi masyarakat, bangsa dan Negara dalam rangka mencapai tujuan ketertiban umum. Penelitian ini ingin memperoleh jawaban atas pertanyaan mengapa masyarakat jalan Stasiun Barat RW 02 Kecamatan Andir bersifat permisif terhadap praktik prostitusi di lingkungannya. Penelitian ini bertujuan untuk mengetahui gambaran mengenai latar belakang masyarakat jalan Stasiun Barat RW 02 Kecamatan Andir cenderung tampak permisif terhadap keberadaan praktik prostitusi yang ada di lingkungannya. Penelitian ini menggunakan pendekatan kualitatif dan menggunakan metode studi kasus. Pendekatan dan metode ini digunakan untuk memahami fenomena sosial mengenai sikap permisif terhadap suatu perilaku menyimpang melalui gambaran menyeluruh. Teknik pengumpulan data dan informasi dilakukan melalui wawancara, observasi, studi dokumentasi, field note, dan studi literatur.
\end{abstract}

Kata Kunci : Permisivisme, Praktik Prostitusi, dan Masyarakat

\section{PENDAHULUAN}

Perilaku manusia kini sangat dipengaruhi oleh lingkungan sekitarnya. Keberagaman bentuk perilaku seseorang, besar kecilnya di pengaruhi oleh lingkungan di sekitar, sebab pada umumnya masyarakat sebagai agen sekunder pembentuk kepribadian memiliki kontribusi yang besar dalam membentuk perilaku seseorang di masyarakat. Perilaku yang dihasilkan tersebut dapat berupa perilaku yang sesuai dengan nilai dan norma yang berlaku, maupun perilaku yang menyimpang dari nilai dan norma, sesuai dengan pengaruh yang diterima individu tersebut. Dalam berperilaku, manusia atau yang termasuk di dalam masyarakat memiliki batasan-batasan dalam melakukan segala sesuatu. Dibutuhkan pengendalian sosial dalam mengatur segala sesuatu yang terjadi di masyarakat. Pengendalian sosial menurut Maftuh dan Ruyadi (1995, hlm. 107) adalah segala proses, baik yang direncanakan maupun tidak, yang bersifat mendidik, mengajak atau bahkan memaksa warga-warga masyarakat agar 
mematuhi norma-norma dan nilai-nilai sosial yang berlaku. Keberadaan dari pengendalian sosial akan membantu masyarakat dalam bertindak, mengetahui batasan-batasan yang dilarang dan mengetahui sejauh mana mereka mendapatkan kebebasan dalam bertindak. Dalam hal ini, masyarakat merupakan subjek serta objek di dalam pengendalian sosial. Dimana, masyarakat yang menentukan suatu aturan dan masyarakat pula yang menjalankan hingga memberikan sanksi. Masyarakat merupakan bagian dari agen pengendali sekaligus yang mesti di kendalikan. Di dalam pengendalian tentunya terdapat aturan, nilai, norma yang diberlakukan. Dibentuk dengan tujuan mencapai ketertiban atau keteraturan bermasyarakat. Disisi lain, tujuan dari adanya pengendalian sosial adalah untuk meminimalisir adanya perilaku yang tidak diinginkan atau menyimpang.

Perilaku menyimpang kerap kali tampak di sekeliling tempat tinggal. Dilakukan secara individu maupun berkelompok. Individu atau kelompok melakukan suatu kegiatan diluar aturan atau nilai dan norma yang berlaku. Sebagaimana yang dikemukakan oleh Sapariah (Willis, 2012, hlm.5) mengartikan perilaku menyimpang sebagai 'tingkah laku yang menyimpang dari norma-norma sosial.'

Perilaku menyimpang tampak diberbagai lapisan masyarakat, terjadi sebab adanya sikap masyarakat yang lari dari aturan, adat dan kebiasaan yang sebelumnya telah ditetapkan. Perilaku menyimpang dapat dikatakan sebagai penyimpangan sosial ketika penyimpangan tersebut dilakukan oleh suatu kelompok bukan lagi dilakukan secara individu. Motif dari individu ataupun kelompok melakukan suatu penyimpangan pun beragam. Dampak yang dihasilkan oleh adanya perilaku menyimpang dapat dirasakan oleh dirinya sendiri maupun orang lain. Perilaku menyimpang merupakan masalah bersama bagi seluruh masyarakat. Masalah sosial yang tak kunjung henti menerpa masyarakat yang lari dari aturan dan dianggap tidak sesuai dengan kebiasaan, tata aturan dan norma yang berlaku. Seperti yang dikemukakan Setiadi dan Kolip (2011, hlm.187), menyatakan bahwa "perilaku menyimpang adalah perilaku dari para warga masyarakat yang dianggap tidak sesuai dengan kebiasaan, tata aturan atau norma sosial yang berlaku." Salah satu contoh dari perilaku menyimpang yang kerap tampak di sekeliling masyarakat yakni praktik prostitusi. Prostitusi atau pelacuran menurut Soekanto (2006, hlm.328) merupakan "suatu pekerjaan yang bersifat menyerahkan diri kepada umum untuk melakukan perbuatan-perbuatan seksual dengan mendapat upah." Mereka semata-mata bekerja untuk memperoleh kepuasan financial maupun biologis.

Praktik prostitusi atau tuna susila dianggap tidak sesuai dengan nilai, norma, kebiasaan, aturan dan hukum yang ada di masyarakat. Cara yang dapat digunakan untuk meminimalisir keberadaan praktik prostitusi salah satunya dengan merealisasikan aturan-aturan yang telah ditetapkan. Karena keberadaan prostitusi maupun mereka yang memberikan fasilitas asusila termasuk kedalam pelanggaran atas ketertiban umum, yang aturannya tertera dalam Peraturan Daerah Kota Bandung No. 3 Tahun 2005 mengenai Penyelenggaraan Ketertiban, 
Kebersihan, Keindahan BAB V tentang Larangan, Pasal 38 poin $f$ sampai $\mathrm{j}$, yang bunyinya:
1. Dilarang melakukan perbuatan asusila;

2. Dilarang menyediakan, menghimpun wanita tuna susila untuk dipanggil, memberi kesempatan kepada khalayak umum untuk berbuat asusila;

3. Dilarang menjajakan cinta atau tingkah lakunya yang patut di duga akan berbuat asusila dengan berada di jalan, jalan hijau, taman dan tempat umum lainnya serta tempat-tempat yang dicurigai akan digunakan sebagai tempat perbuatan asusila;

4. Dilarang menarik keuntungan dari perbuatan asusila sebagai mata pencaharian;

5. Dilarang menyediakan rumah tempat untuk berbuat asusila.

Sudah barang tentu mereka yang melakukan dan memberikan fasilitas bagi praktik asusila atau praktik prostitusi merupakan pelaku penyimpangan (deviant) karena melanggar aturan mengenai ketertiban umum yang telah dipaparkan tersebut. Turut serta masyarakat yang memberi fasilitas dan keuntungan dianggap memberi dukungan dan turut serta dalam keberlangsungan praktik prostitusi. Praktik prostitusi pun dianggap sebagai salah satu bentuk kriminalitas di mata hukum yang aturannya tertera di Kitab Undang-undang Hukum Pidana (KUHP) pasal 296, 297, dan 506 KUHP (dalam Adang, 2010, hlm. 357), menunjukan bahwa 'yang diatur adalah mereka yang menjadi penyalur dan yang mencari wanita untuk tujuan prostitusi.' Selain itu, upaya lain yang dapat dilakuakan dalam meminimalisir keberadaan praktik prostitusi tidak hanya bertitik tolak pada aturan pemerintah saja, namun peran masyarakat sebagai pengendali sosial pun mesti di perhatikan. Seluruh anggota di masyarakat harus mengambil alih atau turut serta dalam pemberantasan penyakit masyarakat itu sendiri. Mengoptimalkan fungsi dari masyarakat sebagai agen pengendali sosial yang menciptakan, menjalankan serta memberikan sanksi bagi mereka yang melanggar aturan yang telah ditetapkan. Dengan adanya upaya masyarakat yang turut serta dalam pemberantasan perilaku menyimpang khsususnya praktik prostitusi, diharapkan masalahmasalah di masyarakat akan berkurang atau terminimalisir.

Namun pada kenyataannya, peneliti menemukan suatu kenyataan yang berbeda di lapangan. Dimana adanya masyarakat sebagai agen of social control atau agen pengendali sosial, justru bersikap acuh terhadap keberadaan perilaku yang menyimpang. Peneliti menganggap adanya pengaruh media massa yang merupakan agen dari globalisasi, sedikitnya mempengaruhi pola pikir serta perilaku masyarakat. Media massa yang mempertontonkan budaya luar yang berbeda dengan budaya lokal pun kini digandrungi oleh masyarakat. Hingga akhirnya eksistensi budaya luar yang tampak di media tersebut pun diikuti oleh masyarakat Indonesia dan pada akhirnya kegandrungan tersebut pun menghasilkan pola pikir serta pola perilaku yang beragam. Media massa kini telah menjadi panutan bagi masyarakat, hal-hal yang dianggap tidak sesuai dengan nilai dan norma pun kini dipertontonkan dan 
dikonsumsi oleh masyarakat umum. Hasilnya masyarakat akan terbiasa dengan adanya perilaku yang melanggar nilai dan norma, kemudian menghasilkan masyarakat yang permisif terhadap nilai, norma, aturan, kebiasaan itu sendiri. Sikap permisif menurut Solihin (2002, hlm.116) merupakan "suatu sikap dan pandangan yang memperbolehkan dan mengizinkan segala-galanya." Sikap permisif tersebut merupakan cerminan masyarakat yang acuh atau serba membolehkan dalam segala hal, termasuk perilaku yang melanggar norma-norma kemasyarakatan. Masyarakat yang permisif cenderung bertindak serba bebas, berperilaku seolah tidak ada adat, kebiasaan, sopan santun, aturan serta hukum. Hal tersebut muncul karena adanya pembiasaan dari masyarakat itu sendiri, biasa menerima pengaruh modernitas dan tidak menghiraukan moralitas yang dianut sebelumnya.

Sikap acuh tersebut dianggap sebagai suatu masalah dalam penelitian ini, terutama sikap acuh masyarakat dalam menangani kasus praktik prostitusi. Perilaku menyimpang berupa prostitusi dapat dilihat di kota-kota besar seperti kota Bandung yang dijadikan sebagai tempat penelitian oleh peneliti. Umumnya praktik prostitusi ini berlangsung pada malam hari. Mulai dari berkerumun di suatu tempat seperti warung, hingga menjajakan kemolekan tubuhnya di sepanjang jalan hingga melakukan praktiknya di tempat-tempat khusus. Hal tersebut dikarenakan pelaku prostitusi merupakan wanita yang menjual kecantikan dan keindahan tubuh yang dibalut dengan pakaian yang tidak sesuai dengan budaya masyarakat
Bandung pada umumnya. Menjual tubuh dan melakukan hubungan seksual tanpa ikatan pernikahan hanya demi memperoleh upah. Mengutamakan urusan duniawi dan mengkesampingkan moralitas.

Keberadaan praktik prostitusi merupakan suatu kasus yang sangat disorot di kota-kota besar lain untuk diberantas, karena dianggap mengganggu ketertiban umum, melanggar norma-norma yang berlaku dimasyarakat, serta dianggap tidak sesuai dengan nilai yang dianut bagi salah satu agama yang mendominasi di daerahnya. Dimana berdasarkan hasil penelitian, hampir $90 \%$ masyarakat Jalan Stasiun Barat RW 02 Kecamatan Andir beragama Islam. Tempat dari praktik prostitusi tersebut berbeda dengan tempat lokalisasi pada umumnya yang memang dikhususkan bagi Pekerja Seks Komersial, keberadaan praktik prostitusi ini berada di tengah-tengah tempat tinggal masyarakat dan sarana-sarana umum seperti Rumah Sakit, rumah makan, Mall dan Stasiun Kereta Api.

Penelitian ini dianggap perlu karena alasan yang telah diutarakan sebelumnya, terutama yang mengundang ketertarikan peneliti adalah tidak adanya kesadaran masyarakat sebagai pengendali sosial untuk memberantas keberadaan praktik prostitusi sementara diketahui jelas lokasi yang digunakan praktik prostitusi tersebut mestinya mengundang banyak penolakan, karena berada di tengah pemukiman masyarakat yang berbeda dengan lokalisasi pada umumnya, serta secara langsung akan mengganggu ketertiban umum. Ditambah masyarakat kota Bandung pada umumnya beragama Muslim yang 
melarang adanya perzinahan atau praktik prostitusi.

Berangkat dari latar belakang yang telah dipaparkan, menggugah peneliti untuk mengetahui secara lebih mendalam mengenai sikap permisif yang ada pada masyarakat jalan

\section{METODE}

Penggunaan pendekatan kualitatif dalam penelitian ini dianggap dapat memberikan gambaran yang alamiah sesuai dengan kondisi dan keadaan yang ada pada objek dan lokasi penelitian serta kesempatan yang lebih untuk peneliti melakukan interaksi dan memahami lebih dalam mengenai masalah sosial tersebut. Sebagaimana pendapat Sugiyono (2014, hlm. 15) "objek yang alamiah adalah objek yang berkembang apa adanya, tidak dimanipulasi oleh peneliti dan kehadiran peneliti tidak begitu mempengaruhi dinamika objek tersebut." Metode penelitian yang digunakan dalam penelitian ini yaitu metode studi kasus. Teknik sampling yang digunakan adalah purposive sampling dan untuk memperoleh hasil lebih baik dilakukan pula snowball sampling.

Penelitian mengenai permisivisme masyarakat terhadap

\section{HASIL DAN PEMBAHASAN}

Pandangan dan Sikap Masyarakat terhadap Praktik Prostitusi di jalan Stasiun Barat

Keberadaan praktik prostitusi di jalan Stasiun Barat RW 02 dipandang oleh masyarakat sebagai suatu bentuk perilaku menyimpang. Hal tersebut dipandang berdasarkan pengetahuan mereka bahwa sesuatu yang tidak sesuai dengan nilai, norma, aturan, kebiasaan, maupun hukum yang berlaku di masyarakat adalah
Stasiun barat RW 02 Kecamatan Andir terhadap keberadaan praktik prostitusi di lingkungannya tersebut. Maka dari itu, peneliti mengambil judul "Permisivisme Masyarakat terhadap Praktik Prostitusi di Kota Bandung"

praktik prostitusi ini dilakukan di jalan Stasiun Barat RW 02 Kelurahan Kebon Jeruk, Kecamatan Andir, Kota Bandung. Informan kunci pada penelitian ini adalah masyarakat jalan Stasiun Barat RW 02, lalu informan pendukung dalam penelitian ini yaitu pelaku prostitusi, masyarakat temporer dan tokoh masyarakat yang dianggap berpengaruh di lingkungannya.

Instrumen dalam penelitian ini yaitu peneliti sendiri yang menjadi instrumen atau alat penelitian. Sugiyono (2005, hlm. 59) menyatakan bahwa "dalam penelitian kualitatif, yang menjadi instrumen penelitian atau alat penelitian adalah peneliti itu sendiri." Serta didukung oleh teknik penelitian yang digunakan untuk memperoleh data melalui observasi, wawancara, field note, studi dokumentasi, dan studi litelatur.

menyimpang. Perilaku sebagian kecil masyarakat yang menggunakan jalan Stasiun Barat sebagai tempat mencari nafkah khususnya praktik prostitusi, menimbulkan pandangan yang beragam di masyarakat. Pada dasarnya masyarakat jalan Stasiun Barat menyadari bahwa praktik prostitusi merupakan salah satu perilaku menyimpang. Karena tidak sesuai dengan kebiasaan dan tata aturan yang berlaku. Kesadaran masyarakat tersebut sesuai dengan 
pendapat Setiadi dan Kolip (2011, hlm.187), yang menyatakan bahwa "perilaku menyimpang adalah perilaku dari para warga masyarakat yang dianggap tidak sesuai dengan kebiasaan, tata aturan atau norma sosial yang berlaku."

Setelah adanya pandangan yang diberikan oleh narasumber terhadap suatu perilaku menyimpang, maka setelah itu akan timbul suatu sikap sebagai bentuk implementasi dalam memandang suatu perilaku menyimpang tersebut. Sikap yang muncul dari masyarakat, baik secara pengakuan langsung maupun pandangan masyarakat lain yang melihat pun berbeda-beda. Masyarakat khususnya tokoh-tokoh berpengaruh seperti Ketua Rukun Warga, Sekretaris Rukun Warga, Sekretaris Rukung Tetangga, maupun pemuka agama dalam menyikapi keberadaan praktik prostitusi di lingkungannya cenderung memilih untuk diam, karena alasan adanya masyarakat tertentu yang memberikan fasilitas. Selama fasilitas terbuka untuk mereka, maka selama itu pula praktik prostitusi akan terus berlangsung. Memilih untuk diam tanpa sikap yang pasti, tidak membolehkan, tidak mengusir, dan tidak pula menghalangi. Sikap yang diambil tersebut mencirikan suatu sikap yang permisif, sesuai dengan yang dicirikan oleh Solihin (2002, hlm. 49) "orang hidup baik boleh, jahat juga boleh. Orang berperilaku etis baik silahkan, buruk tak dilarang".

Penelitian ini menghasilkan pandangan dan sikap masyarakat dimana masyarakat mengetahui bahwa praktik prostitusi adalah perilaku yang menyimpang, namun sikap yang ditunjukan lebih kepada sikap acuh atau memilih diam.
Mencirikan sikap yang permisif, sesuai dengan pendapat yang diutarakan Kadir (2007, hlm. 190) "permisifitas kultural merupakan sebuah aturan nilai dan norma yang longgar. Cenderung membolehkan bahkan mendorong kegiatan pekerja seks beserta sistem pendukung lainnya." Masyarakat cenderung mengizinkan dan membolehkan terbukti dari tidak adanya upaya serius dalam penanggulangannya. Terlihat dari adanya warga yang memelihara, memberikan fasilitas serta upaya yang tidak terfokus pada pengendalian kasus PSK tersebut.

\section{Faktor yang Melatarbelakangi Masyarakat menjadi Permisif terhadap Praktik Prostitusi}

Permisivisme sebagai suatu sikap yang diberikan seseorang dengan serba memperbolehkan, mengizinkan segalanya, bahkan bisa sampai mendorong kegiatan yang dianggap menyimpang tidak dapat dijadikan sebagai jalan penyelesaian suatu masalah. Orang yang permisivisme dalam hidupnya bertindak serba bebas, tidak ada keteraturan dan seolah tidak ada aturan yang pasti. Jauh dari adanya rasa peduli kepada masyarakat sekitarnya. Tidak mencerminkan individu atau masyarakat sebagai kontrol atau pengendali sosial. Di dalam pergaulannya, orang yang permisif akan berperilaku seolah-olah tidak ada kebiasaan, adat, maupun sopan santun. Adanya sikap seperti itu tentunya memiliki dasar atau faktor penyebab.

Faktor permisif salah satunya karena adanya turut serta pihak keamanan yang mencerminkan melemahnya kontrol sosial, terdapat pula hasil penelitian dimana adanya 
penyalahgunaan sikap ramah sebagai ciri orang Sunda. Masyarakat jalan Stasiun Barat yang umumnya adalah orang Sunda, memiliki stereotipe bahwa orangnya ramah. Namun dalam menyikapi praktik prostitusi yang jelas menyimpang, masyarakat justru salah menempatkan sikap ramah tersebut. Memberikan sikap ramah justru memberi kesan bahwa masyarakat tersebut tidak menghiraukan keberadaan perilaku menyimpang di lingkungannya.

Masyarakat tertentu tidak mau memberantas PSK dan justru memelihara karena adanya faktor saling memenuhi kebutuhan atau seperti sistem symbiosis mutualisme. Dimana pihak PSK dan masyarakat terjalin hubungan saling menguntungkan. Adanya pemasukan bagi pemilik dan penjaga kontrakan, bayaran bagi ojeg pelacur, pelanggan kios-kios pinggir jalan, dan biaya perizinan pada pihak keamanan (Linmas). Selain itu berdasarkan pada penelitian, terdapat pula pihak lain yang mempengaruhi keberlangsungan praktik prostitusi dan dapat dijadikan faktor dari adanya sikap permisif masyarakat, yakni turut serta pihak kepolisian. Dimana adanya hubungan baik yang terjalin antara polisi dengan germo maupun para PSK. Hal tersebut mempengaruhi keberlangsungan praktik prostitusi. Para PSK merasa keberadaannya aman karena ia merasa telah memberikan upeti atau bayaran pada polisi yang beroperasi, selain itu ketika akan diadakannya razia gabungan pun para pelaku prostitusi maupun germo sudah diberitahu terlebih dahulu. Hal tersebut membuat masyarakat pada umumnya merasa tidak ada lagi upaya yang dapat dilakukan, karena polisi sebagai petugas keamanan yang mestinya menegakan hukum justru memberi kelonggaran. Rasa tidak percaya kepada kontrol sosial yang melemah pun diberikan kepeda pemerintah, yang mana dalam menangani kasus prostitusi sejauh ini hanya sebatas rehabilitasi tanpa adanya penyediaan lapangan kerja. Sehingga membuat para PSK kembali lagi pada kebiasaannya untuk mangkal. Upaya pemerintah selalu memberantas tapi tidak sampai tuntas. Tidak adanya upaya saling mendukung antara pihak-pihak pengendali merupakan faktor yang membuat masyarakat menjadi permisif.

Munculnya sikap permisif terbentuk karena faktor minimnya kontrol sosial baik dari pemerintah, aparat keamanan maupun masyarakat, mendapat keuntungan dan adanya pihak tertentu yang melindungi keberadaan praktik prostitusi di jalan Stasiun Barat. Sebagaimana yang diutarakan Mayasari (2011, hlm. x) "Faktor internal meliputi peran tokoh masyarakat, faktor ekonomi, melemahnya kontrol sosial di masyarakat. Sedangkan faktor eksternal yaitu aparat yang melindungi, faktor globalisasi, kebijakan pemerintah." Masyarakat jalan Stasiun Barat RW 02 permisif atas faktor melemahnya masyarakat sebagai kontrol sosial, faktor ekonomi karena adanya hubungan symbiosismutualisme, tidak ada upaya serius dari pemerintah, serta adanya masyarakat dan aparat yang melindungi sehingga menimbulkan ketidak percayaan pada pihak kepolisian. Selain itu faktor keterbatasan pendidikan atau pengetahuan terhadap hukum. Alasan 
ketidak tahuan atau buta terhadap hukum serta keterbelakangan mental dijadikan alasan yang tepat bagi mereka sebagai upaya penyelamatan diri dari aturan hukum yang dikenakan padanya.

\section{Dampak dari Permisivisme Masyarakat terhadap Praktik Prostitusi dan bagi Masyarakat}

Keberadaan praktik prostitusi sebagai bentuk perilaku menyimpang, tentunya memiliki dampak yang dirasakan baik bagi pelaku praktik prostitusi maupun masyarakat di sekeliling lingkungan ia praktik. Diketahui benar bahwa prostitusi memilik dampak bagi dirinya maupun masyarakat luas, mulai dari menimbulkan penyakit bagi penggunanya, memberikan dampak psikologi bagi anak-anak, dan lainlain.

Banyaknya jumlah PSK di jalan Stasiun Barat sudah barang tentu menghasilkan suatu dampak bagi masyarakat. Beragam dampak dirasakan oleh masyarakat, mulai dari merasakan rugi karena banyak anak yang masih kecil jadi mengetahui apa itu PSK, penyalah artian tugas polisi karena sering melihat polisi bersama PSK, serta anggapan bahwa masyarakat yang bukan pelaku disamakan atau digeneralisasikan sebagai pelaku prostitusi. Hal tersebut sesuai dengan penyebab praktik prostitusi menurut Kartono (2009, hlm. 249-251) "mendemoralisasi atau memberikan pengaruh demoralisasi kepada lingkungan khususnya anakanak muda remaja pada masa puber dan adolesensi."

Hal lain yang dihasilkan dari keberadaan PSK yakni adanya image bagi daerah yang menjadi jelek atau rusak. Dengan adanya praktik prostitusi di lingkungannya tentu membuat mereka merasa terganggu, baik dampak yang terasa secara langsung maupun perlahan.

Dampak lain dari adanya sikap permisif masyarakat adalah keuntungan yang diperoleh dari uang sewa rumah, biaya ojeg, dan biaya perizinan. Hal tersebut dapat dikategorikan sebagai dampak posiitif bagi masyarakat tertentu. Keuntungan dari PSK pun tentunya dirasakan oleh pemilik dari rumah kontrakan maupun motel yang ada disekitar sebagai dampak positif.

Keberadaan sikap permisif masyarakat terhadap praktik prostitusi kini sudah tidak mutlak berdampak negatif, namun dampak positif pun kini dirasakan oleh masyarakat yang permisif terhadap keberadaan praktik prostitusi. Selama hal tersebut memberikan keuntungan baginya, maka tidak akan ada penolakan untuk memperoleh pemasukan setiap harinya. Meski jelas tertulis dalam Peraturan Daerah Kota Bandung No. 3 Tahun 2005 mengenai Penyelenggaraan Ketertiban, Kebersihan, Keindahan BAB V tentang Larangan, Pasal 38 poin $\mathrm{k}$ dan I:

1. Dilarang menarik keuntungan dari perbuatan asusila sebagai mata pencaharian;

2. Dilarang menyediakan rumah tempat untuk berbuat asusila.

Namun, masyarakat seolah hidup tanpa adanya aturan dan hukum yang berlaku. Tetap menjalankan usaha yang menurutnya memberikan keuntungan terhadap dirinya, tanpa mempertimbangkan hukuman atau sanksi yang akan diterima. 


\section{Upaya yang Dilakukan Masyarakat untuk Mengatasi Sikap Permisif Masyarakat}

Berdasarkan hasil penelitian mengenai sikap permisif masyarakat terhadap praktik prostitusi yang memiliki dampak bagi masyarakat itu sendiri, mestinya ada penanggulangan. Hal tersebut diwujudkan dalam bentuk tidak hanya penanggulangan bagi pelaku prostitusi, namun penanggulangan bagi masyarakat yang bersikap acuh atau permisif. Menurut Kartono (2013, hlm. 266-268) prostitusi dan bagiannya merupakan masalah sosial perlu ditangani dengan kesungguhan. Pada dasarnya Kartono membagi dua usaha penanggulangan tunasusila yakni "usaha yang bersifat preventif serta tindakan yang bersifat represif dan kuratif."

Masyarakat dalam hal ini yang mestinya dapat menjalankan fungsinya sebagai alat pengendali sosial, justru lebih memilih diam dan acuh. Berger (dalam Muin, 2006, hlm. 180) pengendalian sosial adalah 'berbagai cara yang digunakan masyarakat untuk menertibkan anggota yang menyimpang.'

Upaya yang dilakukan masyarakat khususnya warga RW 02 dalam menangani sikap permisif masyarakat terhadap kasus prostitusi. Tidak hanya menangani kasus praktik prostitusinya, namun lebih kepada menangani sikap dari masyarakat yang acuh. Dan hasilnya sedikit yang dapat menjawab dengan tegas pertanyaan peneliti. Sedikit dari masyarakat memang pernah ada yang melakukan tugasnya sebagai pengendali dengan cemoohan atau ejekan, sesuai dengan cara yang dilakukan untuk mengontrol masyarakat yang menyimpang menurut Maftuh \& Ruyadi melalui (1995, hlm. 110-114)

Cemoohan atau ejekan merupakan salah satu cara atau bentuk pengendalian sosial yang tidak menggunakan kekerasan (persuasif). Serta teguran merupakan cara pengendalian sosial melalui perkataan secara langsung atau melalui tulisan terhadap orang yang melakukan perilaku menyimpang (pelanggaran).

Sejauh ini upaya masyarakat sebagai pengendali sosial pun tidak maksimal, hanya sebatas mengeluarkan argumen yang cenderung saling menyalahkan. Dimana mereka lebih bertitik tolak pada kekuasaan pemerintah yang dianggap memiliki hak penuh untuk memberantas praktik prostitusi di lingkungannya. Tidak ada upaya serius yang dilakukan untuk menanggulangi sikap permisifnya.

Masyarakat mesti mampu menjadi alat kontrol bagi masyarakat lain demi terciptanya ketertiban dan keselarasan dalam bermasyarakat. Memberikan perhatian kepada sesama masyarakat, menciptakan adanya rasa tanggung jawab pada nasip lingkungannya, turut berpartisipasi dalam mebangun dan mengendalikan masyarakat di lingkungannya, serta meyakininya. Namun, dalam kasus yang diangkat oleh peneliti, masyarakat maupun pihak-pihak terkait yang mendukung adanya praktik prostitusi di jalan Stasiun Barat RW 02 tidak dapat menjadi pengendali sosial yang baik. Terbukti dengan adanya pemeliharaan pelaku prostitusi di lingkungannya sehingga keberadaan praktik prostitusi tetap berlangsung. Sebagaimana yang diutarakan dalam teori Hirschi tersebut, mestinya masyarakat sebagai agen pengendali 
sosial dapat mengontrol dirinya sendiri. Karena kontrol internal lebih

\section{SIMPULAN}

Masyarakat di jalan Stasiun Barat RW 02 Kelurahan Kebon Jeruk, Kecamatan Andir, Kota Bandung menyadari bahwa praktik prostitusi yang ada di lingkungannya merupakan salah satu bentuk dari perilaku menyimpang. Sikap yang diperlihatkan masyarakat jalan Stasiun Barat RW 02 terhadap keberadaan praktik prostitusi adalah diam, cenderung serba membolehkan dan tidak peduli. Seorang yang permisif akan mengambil sikap diam, serba membolehkan, dan tidak mempedulikan keadaan di lingkungan sekitarnya sekalipun itu menyimpang. Sikap permisif terhadap praktik prostitusi berlangsung sehubungan dengan melemahnya kontrol sosial dari para agen pengendali sosial, simbiosis mutualisme antar pelaku permisif dengan pelaku penyimpangan, serta minimnya pengetahuan masyarakat terhadap hukum. Ketika sikap permisif terhadap praktik prostitusi terus dipertahankan, maka image dan stereotipe buruk terhadap daerah serta masyarakatnya akan menjadi dampak negatif yang dirasakan. Pembuatan aturan khusus yang terfokus pada upaya mengatasi praktik prostitusi serta adanya pembenahan kontrol sosial pada agen-agen pengendali sosial dapat dijadikan upaya dalam menanggulangi sikap permisif. berpengaruh besar sebelum pada kontrol eksternal.

\section{DAFTAR PUSTAKA}

Adang, Y. A. (2010). Kriminologi. Bandung: PT Refika Aditama.

Kadir, H. A. (2007). Tangan Kuasa dalam Kelamin. Yogyakarta: INSISTPRESS.

Kartono, K. (2009). Patologi Sosial Jilid 1. Jakarta: Rajawali Pers.

Kartono, K. (2013). Patologi Sosial Jilid 1. Jakarta: Rajawali Pers.

Maftuh, B dan Ruyadi, Y. (1995). Sosiologi 1. Bandung: CV Pionir Group.

Mayasari, Y. R. (2011). Faktor-Faktor Penyebab Munculnya Sikap Permisif Masyarakat Terhadap Postitusi Liar. (Skripsi). Jurusan Ilmu Kesejahteraan Sosial, Fakultas IImu Sosial dan IImu Politik, Universitas Jember: Jember.

Muin, I. (2014). Sosiologi SMA/MA. Jakarta: Erlangga.

Pemerintah Daerah Kota Bandung. (2005). Peraturan Daerah No. 3 Tahun 2005 tentang Penyelenggaraan Ketertiban, Kebersihan, dan Keindahan. Bandung: Pemda Kota Bandung.

Setiadi, E. M dan Usman K. (2011). Pengantar Sosiologi, Jakarta: Kencana Prenada Media Group.

Soekanto, S. (2006). Sosiologi Suatu Pengantar. PT. Raja Grafindo Persada: Jakarta.

Solihin, O dan Iwan J. (2002). Jangan Jadi Bebek. Gema Isnani

Sugiyono. (2005). Memahami Penelitian Kualitatif. Bandung: Alfabeta.

Sugiyono. (2014). Metode Penelitian Pendidikan Pendekatan Kuantitatif, Kualitatif, dan R\&D. Bandung: Alfabeta.

Willis, S. (2012). Remaja dan Masalahnya. Bandung : Alfabeta 
